\title{
PARAMETRINIO MOKYMO POVEIKIS JAUNESNIOJO MOKYKLINIO AMŽIAUS (8-10 M.) VAIKŲ JUDESIŲ KŪRYBINGUMUI
}

\author{
Rima Bakienè \\ Lietuvos kūno kultūros akademija, Kaunas, Lietuva
}

Rima Bakienè. Socialinių mokslų (edukologijos) daktarè. LKKA Sportinių žaidimų katedros lektorè. Mokslinių tyrimų kryptis — kūno kultūra, sportas, judesių valdymas.

\section{SANTRAUKA}

Judesiu, veiksmu, ju deriniu išmokimo, praktinio taikymo galimybiu tikslingumo kintamomis sqlygomis, naujujudesiu kūrimo ir kitu klausimu sudètingumas neleidžia apsiriboti vien tik tradiciniais judesiu, veiksmu mokymo metodais, o verčia ieškoti nauju pedagogikos, psichologijos, fiziologijos ir kitais mokslais paremtu metodu, priemoniu, konceptualiai pagristi nauju, sudètingesniu judesiu, veiksmu ir ju deriniu mokymo veiksminguma vaiku amžiaus tarpsniais (Beek, Lewbel, 1995; Skurvydas, 1998; Schmidt, Wrisberg, 2000 ir kt.).

Judesiu, veiksmu išmokimas veiksmingas tik tada, kai išmoktajudesi, veiksma vaikas geba taikyti naujomis salygomis, kai igytas igūdis ilgai atsimenamas, patvarus (Schmidt, 1988, 1991; Skurvydas, Gedvilas, 2000). Moksline problema: ar veiksmingas parametrinis mokymas jaunesniojo mokyklinio amžiaus vaikus mokant atlikti sudètingus judesius, veiksmus naujomis salygomis? Tyrimo tikslas - nustatyti ir ivertinti, kaip parametrinis judesiu mokymas veikia jaunesniojo mokyklinio amžiaus vaiku sudètingujudesiu išmokimo kūrybingumq.

Norint išsiaiškinti parametrinio ir standartinio mokymo poveiki jaunesniojo mokyklinio amžiaus vaiku judesiu kūrybingumui, buvo atliktas pedagoginis eksperimentas, kurio metu tirti 45 (24 berniukai ir 21 mergaitès) Kauno miesto $N$ vidurinès mokyklos trečios klasès mokiniai. Pedagoginiame eksperimente dalyvavo dvi mokiniu klasès (grupès): kontroline ir eksperimentiné. Kontroliné mokiniu grupé - tai standartinio mokymo vaiku grupé, eksperimentiné - parametrinio mokymo grupe.

Atlikus eksperimenta galima teigti, kad parametrinis sudètingujudesiu mokymo metodas pasikeitus išorès salygoms (krypčiai ir atstumui), bet nekeičiant judesiu struktūros, yra veiksmingesnis vaiku gebejjimui atkurti ir pritaikyti anksčiau išmoktus judesius, ju derinius naujomis salygomis - judesiu kūrybingumui. Lyties požiūriu tirtu 8-10 metu mergaičiu ir berniuku nauju, sudètingu judesiu, ju deriniu atsiminimo, atkūrimo ir pritaikymo naujomis salygomis (judesiu kürybingumo praejjus ilgesniam laikui) kiekybiniai ir kokybiniai rodikliai geresni buvo berniuku $(p<0,05)$.

Raktažodžiai: parametrinis mokymas, mokymas kintamomis ir standartinemis sqlygomis, jaunesnysis mokyklinis amžius, judesiu kūrybingumas.

\section{IVADAS}

A ktualumas. Vienas iš pagrindiniu kūno kultūros teorijos, didaktikos specialistų tyrimo objektų yra žmogaus judèjimo galimybių, t. y. žmogaus organizmo savybių ir ypatybių komplekso būsenos, leidžiančios atlikti tam tikrus judesius, veiksmus, tyrimas.

Judesių, veiksmų, jų derinių išmokimo, praktinio taikymo galimybių tikslingumo kintamomis, naujomis sąlygomis, naujų judesių kūrimo ir kitų klausimų sudetingumas neleidžia apsiriboti vien tik tradiciniais judesių, veiksmų mokymo meto- dais, o verčia ieškoti naujų, pedagogikos, psichologijos, fiziologijos ir kitais mokslais paremtu metodu, priemoniu, konceptualiai pagristi naujų sudètingesnių judesių, veiksmų ir jų derinių mokymo veiksmingumą vaikų amžiaus tarpsniais (Beek, Lewbel, 1995; Skurvydas, 1998; Schmidt, Wrisberg, 2000 ir kt.).

Tyrimų aktualumas dar labiau išryškèja susipažinus su daugelio autoriu pateiktomis judesių ugdymo tyrimų išvadomis, teorinèmis prielaidomis, iš kurių kyla ne vienas probleminis 
klausimas: kuriuo mokymo metodu standartiniu (nekintamomis sąlygomis) ar parametriniu (kintamomis sąlygomis) mokyti atlikti naują judesi, veiksmą ir koks tų metodų poveikis vaikų judesių kūrybingumui?

Mokslinė problema. Suvokus, kad judesiu, veiksmų išmokimas veiksmingas tik tada, kai išmoktą judesị, veiksmą vaikas geba taikyti naujomis sąlygomis, kai igytas igūdis ilgai atsimenamas, patvarus (Schmidt, 1988, 1991; Skurvydas, Gedvilas, 2000), buvo apibrèžtas parametrinis judesių mokymas.

Parametrinis mokymas — tai judesių, veiksmu, jų derinių mokymo būdas nuolat keičiant judesių mokymo kiekybinius dydžius (atstuma, krypti ir kt.), ìveikiant išorini (kliūtis, varžovą) ir vidini (nuovargi, jaudinimąsi) pasipriešinimą (Sporto terminu žodynas, 2002).

Taikant parametrini mokymą vaikai: atlieka ir išmoksta daugiau įvairių judesių, veiksmų, dèl to išmoktus judesius veiksmingiau taiko naujomis sąlygomis. Mokant naujų judesių, tobulinant juos, būtina skatinti vaikų kūrybingumą: gebejjimą savarankiškai mąstyti, greitai susivokti naujomis situacijomis, ieškoti ir rasti naujų sprendimu (Adaškevičienè, 1994; Kelso, 1999; Dolonec et al., 2002 ir kt.).

Šie teiginiai pagristi tik laboratorinių tyrimu metu mokant paprastu judesiu.

Todèl iškyla mokslinè problema: ar veiksmingas parametrinis mokymas mokant jaunesniojo mokyklinio amžiaus vaikus atlikti sudetingus judesius, veiksmus, norint juos taikyti naujomis sąlygomis?

Darbinė hipotezė: kai jaunesniojo mokyklinio amžiaus vaikai mokomi taikant parametrini sudètingu judesių metodą, jie turètu gebèti atlikti tuos judesius kintamomis sąlygomis, kurti naujus.

Tyrimo tikslas - nustatyti ir ivertinti, kaip parametrinis judesių mokymas veikia jaunesniojo mokyklinio amžiaus vaikų sudėtingų judesių išmokimo kūrybingumą.

\section{TYRIMO METODAI}

Tyrimui atlikti buvo taikytas pedagoginio eksperimento metodas. Pedagoginiame eksperimente dalyvavo dvi mokinių klasès (grupès): kontrolinè ir eksperimentinè. Kontrolinè mokiniu grupe - tai standartinio mokymo vaiku grupé, eksperimentinè - parametrinio mokymo grupè. Standartinio mokymo mokiniu grupè per kūno kultūros pamokas buvo mokoma naujų sudètingų judesiu standartiniu būdu. Šio mokymo esmè tokia: nauju judesių mokoma nekintamomis sąlygomis, t. y. vaikas aktyviai mokomas vieno judesio, veiksmo nuolat ji kartojant, vaiko dèmesys sukauptas, ir visos pastangos nukreipiamos vienai užduočiai atlikti, kai jam nereikia nieko rinktis, niekas jam netrukdo.

Parametrinio mokymo grupè naujų sudètingu judesiu mokèsi parametriniu būdu. Šio metodo esmè tokia: nauju judesių mokoma kintamomis sąlygomis, t. y. kintant judesių, veiksmų atlikimo sąlygoms (atstumui, krypčiai ir kt.), ivveikiant išorini pasipriešinimą (kliūtis, varžovą), renkantis sprendimus, esant nuovargiui ir pan. Eksperimento metu buvo mokoma sudètingų, tikslumo reikalaujančiu judesiu — metimu i krepši iš vietos.

Tiriamieji. Tiriamają imti sudare 45 (24 berniukai ir 21 mergaitès) trečių klasių mokiniai (amžiaus vidurkis $-9 \pm 0,5 \mathrm{SK}$ ). Taikème klasterini tiriamosios imties parinkimo būdą, kurio pagrindinis atrankos vienetas buvo klasè. Atliekant eksperimentini tyrima, atsitiktinis mokinių parinkimo būdas netiko. Tyrimui pasirinkome Kauno N vidurinę mokyklą, vienintelę mieste, kurioje vyko trys kūno kultūros pamokos per savaitę, ir tai buvo viena iš eksperimento sąlygų. Viena klasè atsitiktiniu būdu buvo priskirta poveikio grupei $(\mathrm{n}=25)$, kita kontrolinei $(n=25)$. Vaikai, kurie po pamokų papildomai lanke krepšinio pratybas, eksperimente nedalyvavo: poveikio klasėje buvo $23(\mathrm{n}=23)$, o kontrolinèje 22 $(\mathrm{n}=22)$ tiriamieji.

Prieš eksperimentą abi mokinių grupès atliko vienodą pradini testą. Šio testo paskirtis ivertinti tiriamuju grupių parengtumą pradedant eksperimentą. Pradinis testas buvo atliekamas standartinèmis sąlygomis: $(5 \times 10$ serijų $=50$ metimu), metimai atliekami nuo baudų metimo linijos.

Eksperimento metu standartinio mokymo grupés tiriamieji atliko kamuolio metimus i krepši standartinèmis sąlygomis $(5 \times 10$ seriju $=50$ metimu). Metimai atliekami nuo baudų metimo linijos iš $4 \mathrm{~m}$ atstumo (1 pav.).

Parametrinio mokymo grupés tiriamieji atliko metimus $\mathfrak{i}$ krepši kintamomis sąlygomis $(5 \times 10$ seriju $=50$ metimu $)$. Metimai atliekami iš penkių skirtingų $4 \mathrm{~m}$ nuo krepšio atstumo taškų: 0,45 , $90,45,0^{\circ}$ ( 2 pav.).

Sudarytu pratimu programa buvo taikoma 7-8 savaites. Tuo metu buvo stebimas standartinio ir parametrinio mokymo grupès nauju judesių 
išmokimo vyksmas. Paskui 2 mėnesius stebètas eksperimente taikyto standartinio ir prametrinio mokymo poveikis, t. y. gebejimas kuo ilgiau atsiminti išmoktus judesius. Todèl po 1 ir po 2 mènesiu abieju grupių mokiniai vèl buvo testuojami atliekant naują testą. Naujas testas (nauja situacija) abiems grupèms buvo vienodas. Šiuo testu buvo įvertinamas mokiniu kūrybingumas, t. y. kaip jie geba pritaikyti išmoktus judesius naujoje situacijoje, metant kamuoli i krepši iš 5 skirtingu (1, 3, 4- $4 \mathrm{~m}, 2$ ir $5-3 \mathrm{~m})$ tašku (3 pav.).

Pasibaigus eksperimentui, t. y. po 20 pamoku, mokiniams vyko kūno kultūros pamokos pagal vidurinès mokyklos programą, nenaudojant jose pagrindinių krepšinio judesių (veiksmų). Pedagoginio eksperimento schema pateikta 4 paveiksle.

1 pav. Kamuolio metimai i krepši iš vietos standartinèmis sąlygomis

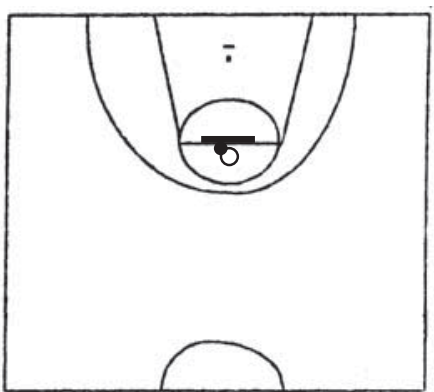

2 pav. Kamuolio metimai i krepšį iš vietos kintamomis sąlygomis

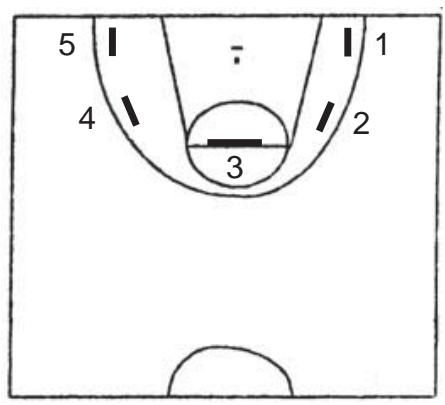

3 pav. Kamuolio metimų i krepši iš vietos nauja situacija

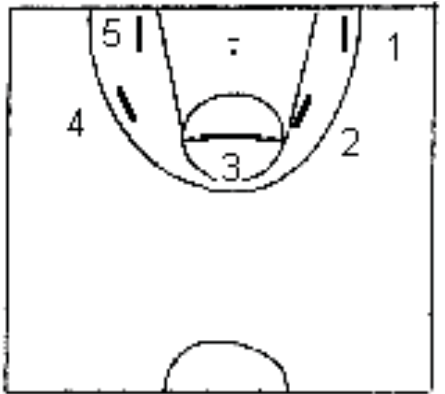

Abi mokiniu grupès metė mažojo krepšinio kamuolius $(450 \mathrm{~g})$ metė i $260 \mathrm{~cm}$ aukščio krepšius.

Testavimas. Prieš pradedant naujų sudètingų judesių mokymą, vyko pradiniai testavimai, kurių metu įvertinome visu tiriamuju lygi prieš eksperimentą. Išmoktų judesių kūrybingumas ir veiksmingumas buvo vertinamas pagal kokybinius (metimo veiksmo taisyklingumą) ir kiekybinius (tikslius metimus) rodiklius. Netaisyklingai metus, tikslus metimas nebuvo įskaitomas.

Matematine statistika. Apdorojant gautus testavimo duomenis, nustatant testavimo vidutinių rodiklių skirtumo statistini reikšmingumą, buvo naudotas $t$ (Stjudento) kriterijus, taikytas porinèms imtims. Jei $p$ reikšmès didesnès už $0,05(p>0,05)$, buvo laikoma, kad skirtumas tarp duomenų nepatikimas. Priešingu atveju skirtumas tarp lyginamuju duomenų statistiniu požiūriu buvo laikomas patikimu $(\mathrm{p}<0,05)$, labai patikimu $(\mathrm{p}<0,01)$ arba itin patikimu $(\mathrm{p}<0,001)$. Prireikus patikrinti hipotezę dèl daugiau nei dviejų vidurkiu lygybès, buvo taikytas F kriterijus. Taip pat buvo apskaičiuojamas aritmetinis vidurkis $(\overline{\mathrm{X}})$, vidutinis kvadratinis nuokrypis $(\sigma)$, aritmetinio vidurkio paklaida $(\mathrm{S} \overline{\mathrm{x}})$.

Tyrimo organizavimas. Eksperimentas pradètas vykdyti $2000 \mathrm{~m}$. spalio $3 \mathrm{~d}$. ir baigtas $2001 \mathrm{~m}$. sausio 30 d. Eksperimentui vykdyti buvo isigytas specialus inventorius: 3 krepšinio stovai su $260 \mathrm{~cm}$ aukštyje esančiais lankais, pritaikytais mažajam krepšiniui, ir 25 mažojo krepšinio kamuoliai.

\section{REZULTATAI}

Eksperimento metu tirtų vaikų ( 8 -10 metų amžiaus) judamasis (motorinis) parengtumas buvo adekvatus: standartinio ir parametrinio mokymo grupiu pradinio testavimo, atlikto prieš eksperimentą, metimu i krepši iš vietos rodikliai buvo panašūs, ir tai patvirtina statistiškai nepatikimas vidutinių $(\mathrm{p}>0,05)$ standartinio ir parametrinio mokymo grupių vaikų testavimo rodiklių skirtumas (žr. lent.).

Mokantis sudètingų, tikslumo reikalaujančių judesių (metimų $\mathfrak{i}$ krepši iš vietos) tiek standar-

\footnotetext{
4 pav. Pedagoginio eksperimento schema

Pastaba. $\stackrel{\text { A }}{\longleftrightarrow}-$ mokymas standartinėmis sąlygomis; $\stackrel{\mathrm{B}}{\longrightarrow}$ - mokymas kintamomis salygomis; pertrauka - kūno kultūros pamokos, vykdomos pagal vidurinės mokyklos programą.
}

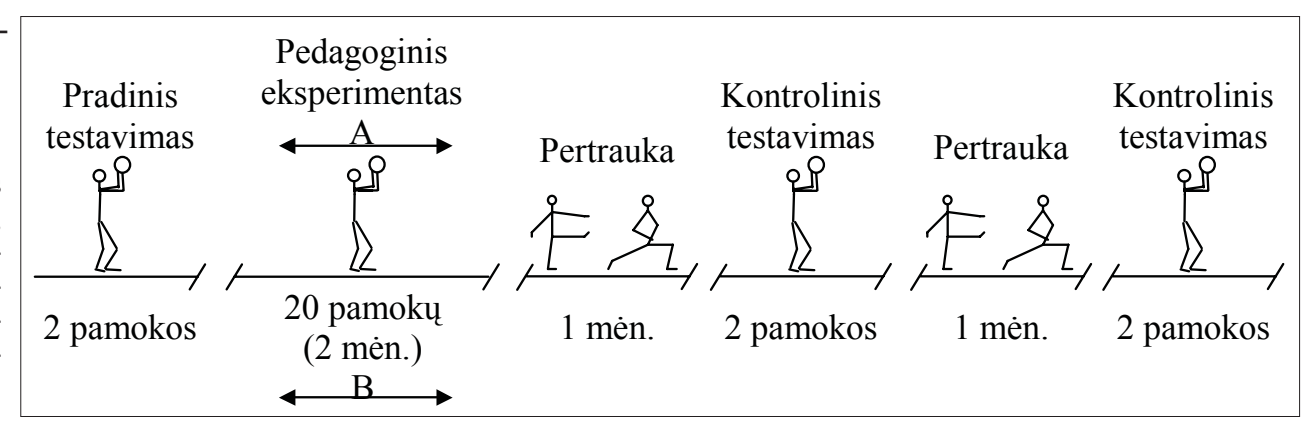




\begin{tabular}{|c|c|c|}
\hline \multirow{2}{*}{ Rodikliai (pataikymo) } & \multicolumn{2}{|c|}{ Grupès } \\
\cline { 2 - 3 } & Standartinio mokymo & Parametrinio mokymo \\
\hline$\overline{\mathbf{X}}$ & 9,0 & 12,3 \\
$\sigma$ & 5,6 & 7,2 \\
maks. & 17 & 22 \\
min. & 1 & 2 \\
\hline
\end{tabular}

Lentelè. Standartinio ir parametrinio mokymo grupių pradinio testavimo, metimu i krepši iš vietos rodiklių reikšmès $(\overline{\mathbf{X}} ; \pm \sigma$; maks.; min.)

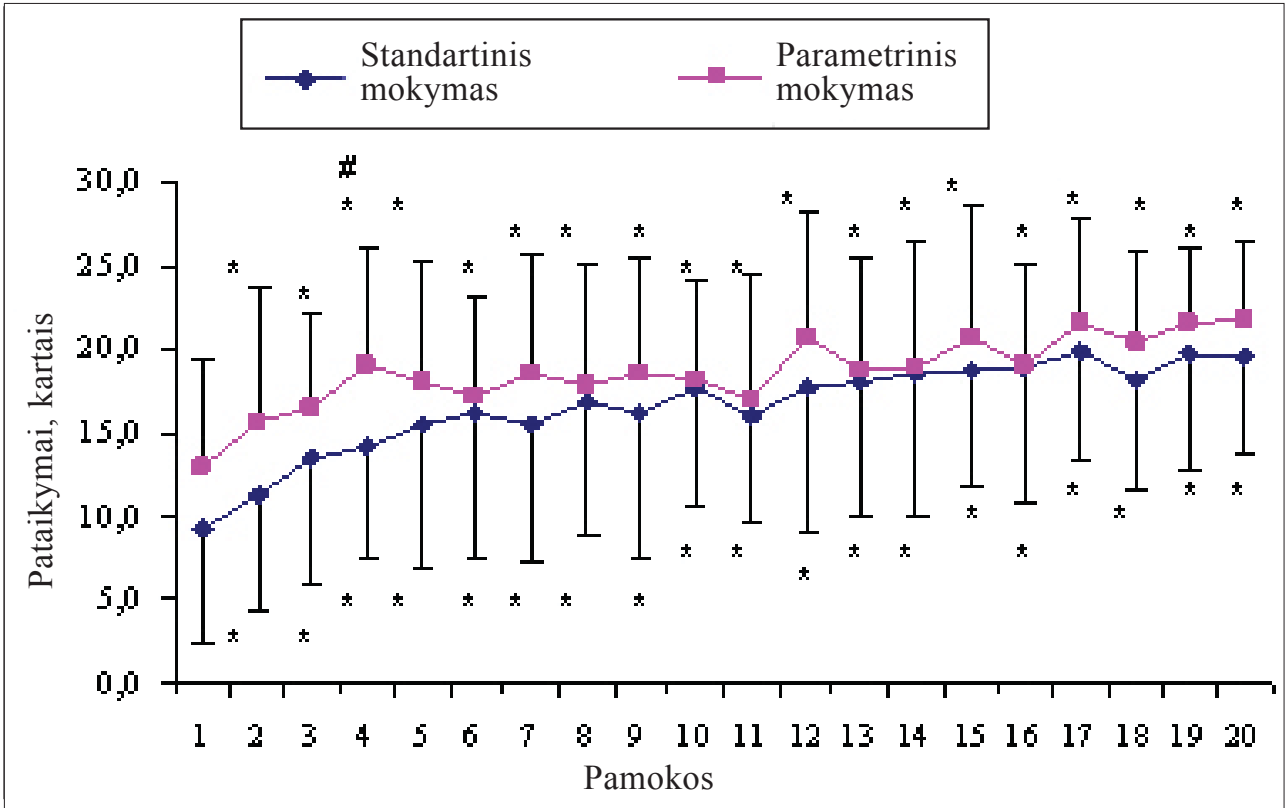

5 pav. Standartinio ir parametrinio mokymo grupių metimų i krepši iš vietos judesių išmokimo vyksmo rodikliai

Pastaba. * - p $<0,05$, lyginant su pirmos pamokos rodikliu vidurkiu toje pačioje grupeje; $\#-p<0,05$, lyginant rodiklius tarp abiejų grupių.

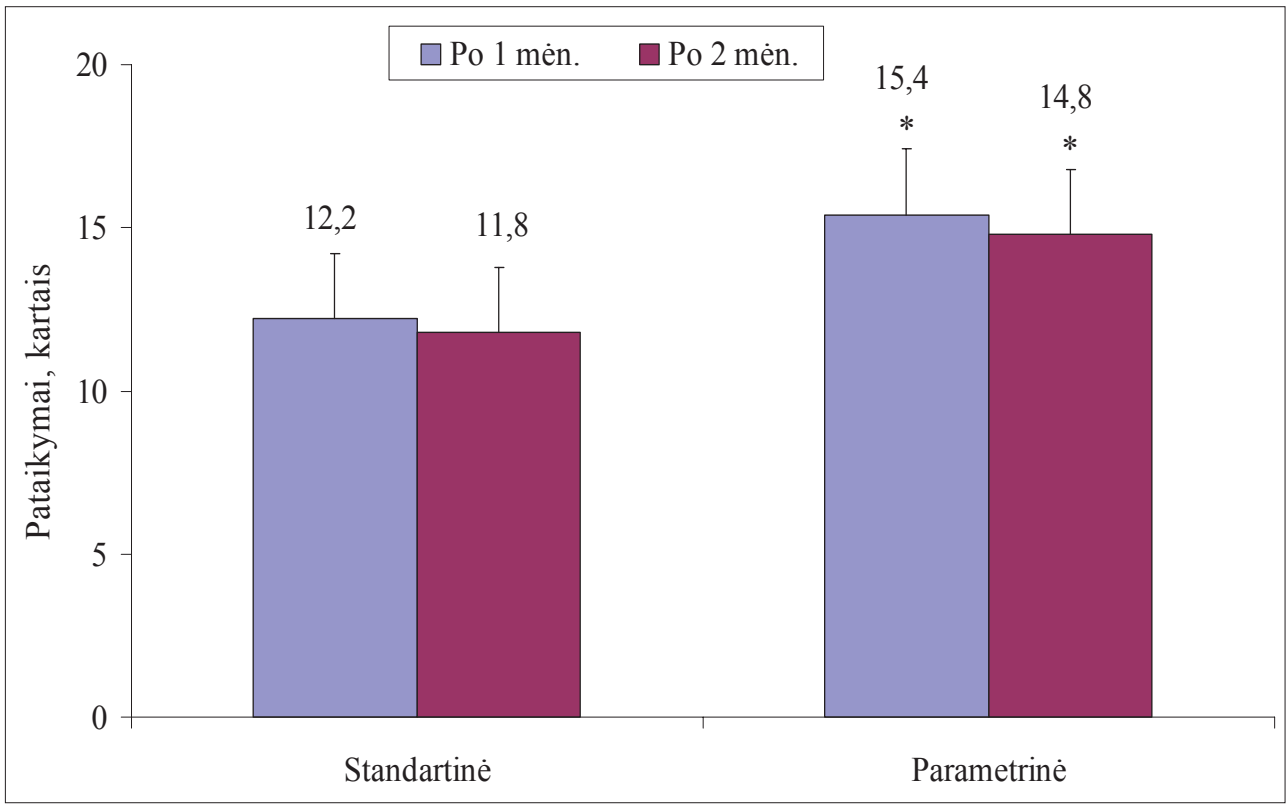

6 pav. Standartinio ir parametrinio mokymo grupių metimų i krepši išmoktu judesių pritaikymo naujoje situacijoje rodikliai

Pastaba. * - p < 0,05, lyginant standartinio mokymo ir parametrinio mokymo grupių rodiklius.

tiniu, tiek parametriniu būdu, išmokimo, judesių ivvaldymo vyksmas, jo veiksmingumas beveik nesiskyrè: jau nuo antros pamokos abiejų grupių vaikų judesių išmokimas (vidutiniai judesių tikslumo rodikliai) statistiškai patikimai skyrèsi nuo pirmoje pamokoje užfiksuotu (žr. 5 pav.), o vidutinių standartiniu ir parametriniu būdu mokomų judesių išmokimo rodiklių skirtumas tarp grupių buvo statistiškai nepatikimas $(\mathrm{p}>0,05)$.
Atlikus pedagogini eksperimenta, standartinio mokymo grupès, kurios mokiniai buvo mokomi kamuolio metimų i krepši iš vietos standartinèmis sąlygomis, ir parametrinio mokymo grupès judesių atlikimo tikslumo rodikliai smarkiai pagerèjo $(\mathrm{p}<0,05)$.

Norint įvertinti judesių mokymo standartinèmis ir kintamomis sąlygomis poveiki išmoktų judesių atsiminimui ir taikymui naujomis situa- 


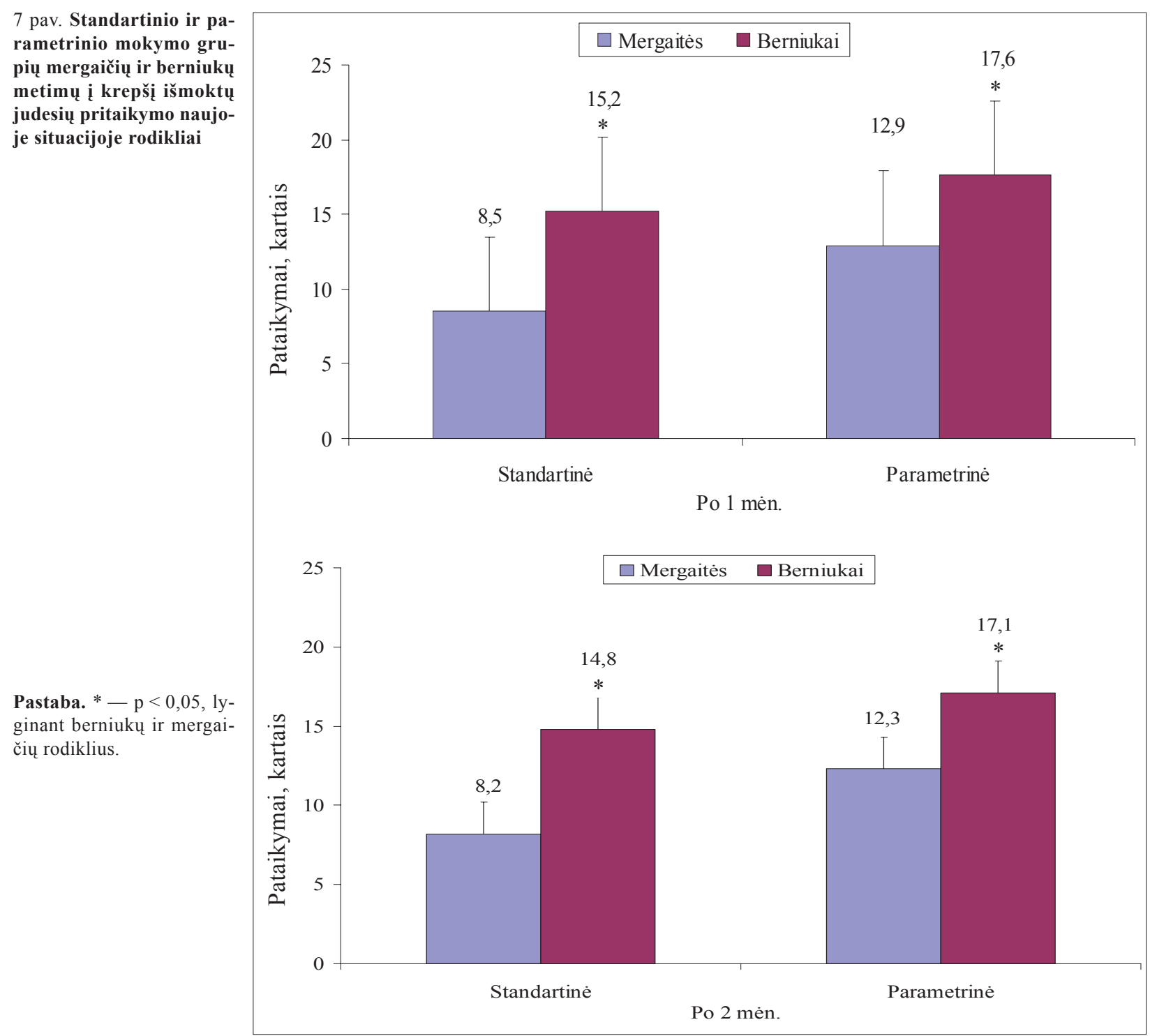

cijomis, t. y. kūrybingumui, abieju grupių tiriamiesiems buvo sukurta vienoda nauja situacija, kuriai esant išmoktus judesius, veiksmus reikejo taikyti pasikeitus atliekamų judesių krypčiai, atstumui. Šis eksperimentas parode vaiku gebèjimą pritaikyti anksčiau išmoktus judesius naujomis, nežinomomis situacijomis, t. y. judesių kūrybingumą.

Po 1 ir 2 ménesiu po eksperimento, taikant naujos situacijos testą (6 pav.), eksperimentinès mokiniu grupès rodikliai buvo geresni. Tai patvirtina statistiškai patikimas vidutinių testavimo rodiklių skirtumas tarp abiejų grupiu $(\mathrm{p}<0,05)$.

Vertinant vaikų kūrybingumą, t. y. gebejjimą išmoktus judesius taikyti naujomis situacijomis lyties požiūriu, buvo gautas didelis berniukų ir mergaičiu rodikliu skirtumas abiejose mokymo grupèse (7 pav.).

\section{REZULTATŲ APTARIMAS}

Interpretuodami ir vertindami mūsų tyrimo sudètingų judesių, veiksmų, jų derinių išmokimo vyksmo ir vaikų kūrybingumo, atsimenant bei taikant išmoktus judesius naujomis situacijomis duomenis, naudojome teiginius ir išvadas, gautas mokant palyginti nesudètingu judesių, veiksmų.

Nustatant ir vertinant vaiku judejimo gebejimus, jų kaitą, tai daryti būtina vertinant ne atskiro judesio, jo dalies išmokimą, o visumą (Bonacin et al., 2002). Svarbūs rodikliai čia yra judesiu atlikimo greitumas (kiekybiniai rodikliai) ir judesių tikslumas (kokybiniai rodikliai), judesių atlikimo greitumo ir tikslumo suderinimas (Сковородникова, Голомазов, 2000). Nauju јudesiu mokymo veiksmingumą vienokiomis ar kitokiomis sąlygomis rodo užduoties (mokomu judesių, veiksmų) įvaldymo greitis mokymo vyks- 
me arba (ir) tų judesių išmokimo lygis mokymo pabaigoje (Druckman, Bjork 1991).

Gauti rezultatai mokant sudètingų, tikslumo reikalaujančių judesių (metimų i krepši iš vietos) tiek standartiniu, tiek parametriniu būdu buvo panašūs, nors ju prieaugis nuo 8 pamokos buvo geresnis standartinio mokymo grupeje. Čia pasitvirtino daugelio autorių (Bjork, 1979; Shea, Zimny, 1983 ir kt.) padaryta išvada tiriant paprastų judesiu mokymo veiksmingumą: vaikai naujų judesių greičiau išmoksta mokydamiesi jų standartiniu, o ne parametriniu metodu. Galutiniai abieju grupių vaikų naujų judesių išmokimo rodikliai pasibaigus mokymui buvo panašūs: mokomų judesių tikslumo rodikliai, lyginant su pirmo testavimo rodikliais, smarkiai pagerèjo $(\mathrm{p}<0,05)$.

Kintamos judesių mokymo sąlygos, kai keitèsi tik judesiu atlikimo vieta (metimu i krepši kryptis), o kiti dydžiai (t. y. atstumas) nekito, neturejo esminio poveikio vaikų judesių išmokimui.

Gana sparčiai naujų judesių buvo išmokstama, kai jų mokoma kintant tik atliekamų judesių vietai taikinio atžvilgiu, gal dèl to, kad pradinis mokomu judesių tikslumas (siekęs tik apie 12\%, žr. 5 pav.) buvo mažas, o mokantis naujų judesių veiksmų mokymosi pradžioje išmokimo kokybè gereja sparčiai, vèliau ji keičiasi lèčiau (Schmidt, Wrisberg, 2000; Rajtmajer, Vehovar, 2002).

R. A. Schmidt (1991) svarbiausiu judesiu mokymo ir tobulinimo tikslu laikè vaiko vidiniu galimybių išplètojimą - kad jis ateityje galètų atlikti ịvairius judesius, veiksmus įvairiomis situacijomis, t. y. išmoktus judesius taikytų kūrybingai.

Nustatant ir įvertinant vaiku judèjimo gebèjimus, judesių atlikimą, kintant jų dydžiams, naujomis situacijomis, tikslinga vertinti ne atskirus judesius, o jų visumą. Todèl žaidimo testai, atliekant keletą technikos veiksmu, gerai parodo vaiku judejjimo gebejjimus (Bonacin et al., 2002).

Parametrinio mokymo grupès tiriamieji 8 $10 \mathrm{~m}$. vaikai sudètingus, tikslumo reikalaujančius judesius, jų derinius (kamuolio metimų i krepši iš vietos) geriau atsiminè ir naujomis situacijomis (kintant judesių krypčiai ir atstumui) kūrybingiau juos pritaikè (6 pav.): abieju grupių vaiku vidutinių testavimo rodiklių skirtumas praejus 1 ir 2 mėnesiams po eksperimento skyrèsi statistiškai patikimai $(\mathrm{p}<0,05)$. Tai nèra sunku paaiškinti, nes mūsų tyrimo duomenys iš esmès sutampa su daugelio autoriu, tyrinejjusių vaiku galimybes ir gebejjimus atsiminti bei pritaikyti išmoktus nesudètingus judesius naujomis sąlygomis. Jie teigia, kad parametrinis (kintamomis sąlygomis) judesių mokymas yra labai svarbus norint sudaryti judesių atlikimo schemas (Schmidt, 1991; Skurvydas, 1998 ir kt.), kad judesiu mokymas kintamomis sąlygomis leidžia vaikams išmokti ịvairesniu judesių, ugdo gebejjimus prisitaikyti prie naujų sąlygų, todèl jie greičiau ívaldo tokius judesius, kurių anksčiau neatlikdavo (Wrisberg, 1991).

Lyties požiūriu išmoktų judesių pritaikymo naujoje situacijoje, t. y. kūrybingumo, rodikliai smarkiai skyrèsi tarp mergaičiu ir berniukų abiejose mokymo grupèse. Sudètingus, tikslumo reikalaujančius judesių derinius (kamuolio metimu i krepši iš vietos) naujoje situacijoje (kintant judesio krypčiai ir atstumui) tiek standartinio, tiek parametrinio mokymo grupių berniukai atliko geriau nei mergaitės $(\mathrm{p}<0,05)$ (žr. 7 pav.).

Galima teigti, kad mokant sudètingų nauju judesių derinių parametrinis mokymas kintamomis sąlygomis labiau veikia $8-10 \mathrm{~m}$. vaiku judesių ìsiminimą, jų taikymą naujomis sąlygomis, t. y. judesių kūrybingumą.

\section{IŠVADOS}

1. Mokant jaunesniojo mokyklinio amžiaus vaikus sudètingų, tikslumo reikalaujančių judesių bei jų derinių standartinio ir parametrinio mokymo poveikis judesių mokymosi vyksmui yra panašus. Mokant sudètingų tikslumo reikalaujančių judesių parametriniu būdu, kai nèra vidinių kliūčių (nuovargio), o kinta tik išorès sąlygos (atstumas, kryptis), standartinio ir parametrinio metodų veiksmingumas išmokimo vyksmui yra adekvatūs.

2. Standartinio ir parametrinio sudètingų judesių mokymo metodu poveikio rodikliai vaiku gebejjimui atkurti ir pritaikyti anksčiau išmoktus judesius, jų derinius naujomis sąlygomis - judesių kūrybingumui — geresni parametrinio metodo mokymo grupejje. Sudetingus judesius, reikalaujančius tikslumo naujomis sąlygomis, pasikeitus išorinèms sąlygoms (krypčiai ir atstumui), bet nekintant judesių struktūrai, parametrinio mokymo grupès vaikai atsiminè ir pritaikè naujomis sąlygomis geriau.

3. Lyties požiūriu tirtų mergaičių ir berniukų naujų, sudètingu judesių, jų derinių atkūrimo, atgaminimo ir pritaikymo naujomis sąlygomis (judesių kūrybingumo praejjus ilgesniam laikui) kiekybiniai ir kokybiniai rodikliai geresni buvo berniuku ( $p<0,05)$. 


\title{
LITERATŪRA
}

Adaškevičienè, E. (1994). Vaiku fizinio ugdymo pedagogika. Vilnius: Egalda.

Beek, P. J., Lewbel, A. (1995). The science of juggling. Scientific American, 273, 92-97.

Bjork, R. A. (1979). Retrieval Practice: Unpublished Manuscript. Los Angeles: University of California.

Bonacin, D., Pažanin, R., Katiae, R. (2002). Development of the coordination integration in boys aged $7-9$ years. Sixth International Scientific Congress "Modern Olympic Sport and Sport for All”, June 6-9 (pp. 649-650). Warsaw.

Dolonec, M., Pistotnik, B., Pinter, S. (2002). Correlation between co-ordination and cognitive abilities of girls 7 to 11 years of age. 3rd International Scientific Conference "Kinesiology New Perspective": Proceedings Book. Croatija, Opatija.

Druckman, D., Bjork, R. A. (1991). In the Mind's Eye: Enhacing Human Performance. Washington, D. C.: National Academy Press.

Kelso, J. A. S. (1999). Dynamic Patterns: The Self-organisation of Brain and Behavior. Massachusetts Institute of Technology.

Rajtmajer, D., Vehovar, M. (2002). Early learning of complex motor structures. 3rd International Scientific Conference "Kinesiology New Perspectives": Proceedings Book. Croatija, Opatija.
Schmidt, R. A. (1988). Motor Control and Learning (A Behavioral Emphasis). Human Kinetics.

Schmidt, R. A. (1991). Motor Learning and Performance. From Principle to Pperformance. Human Kinetics.

Schmidt, R. A., Wrisberg, C. A. (2000). Motor Learning and Performance. USA: Human Kinetics.

Shea, J. B., Zimny, S. T. (1983). Context effects in memory and learning movement information. In R. A. Magill (Ed.), Memory and Control of Action (pp. 345-366). Amsterdam: Elsevier.

Skurvydas, A., Gedvilas, V. (2000). Fiziniu ypatybiu lavinimo teorija ir metodika. Kaunas: LKKA.

Skurvydas, A. (1998). Judesiu valdymo ir sporto fiziologijos pagrindai. Kaunas: LKKI.

Sporto terminu žodynas. (2002). Parengè S. Stonkus. T. 1. Kaunas: LKKA.

Wrisberg, C. A. (1991). A field test of the effect of contextual variety during skill acquisition. Journal of Teaching in Physical Education, 11, 21-30.

Сковородникова, Н. В., Голомазов, С. В. (2000). Возрастная динамика проявления быстроты и целевой точности школьников и юных баскетболистов. Физическая культура, 1, 2-5.

\section{IMPACT OF PARAMETRIC TEACHING ON THE CREATIVENESS OF MOVEMENTS OF JUNIOR SCHOOL AGE (8 - 10 YEARS) CHILDREN}

\author{
Rima Bakienè \\ Lithuanian Academy of Physical Education, Kaunas, Lithuania
}

\begin{abstract}
The complexity of answers to the course of learning movements and actions and their combinations, the questions of possibilities of practical application of retaining them in new, changeable conditions, formation of new movements, etc. do not allow us to restrict ourselves to merely using the traditional methods of teaching movements and actions but forces us to search for new methods based on pedagogics, psychology, physiology and other sciences, as well as to search for means that would provide a conceptual basis for efficient teaching of complex movements and actions and their combinations in the junior school age. That's why research of parametrical teaching of complex movements in the junior school age is topical (Beek, Lewbel, 1995; Skurvydas, 1998; Schmidt, Wrisberg, 2000 et al.).

Learning movements and actions is only efficient if the child is able to apply this movement and action correctly under new conditions. Thus, the skill is retained for a long time (Schmidt, 1988, 1991; Skurvydas, Gedvilas, 2000). Scientific problem: is parametric method of learning efficient in teaching complex movements and actions in order to apply them under new conditions? The aim of the research: to establish and estimate the impact of the parametric method to the creativness of complex movements learnt while teaching boys and girls of the junior school age. In order to clear up an impact of the parametrical and standard method the pedagogical experiment was carried out. There were 45 ( 24 boys and 21 girl) children of the junior school age participating in the experiment. Two classes (groups) of shoolchildren participated in the pedagogical experiment: control and experimental. The control one was a group of standard teaching, the experimental group — of parametric teaching. After carrying out the pedagogical experiment it became clear that parametrical method of teaching was more efficient to the creativeness of movements learnt. The children from parametric teaching group better retained and applied complicated movements under new circumstances - direction or distance, but not altering the structure of movements. The boys of junior school age better applied newly learnt movements $(p<0,05)$ in new situations.
\end{abstract}

Keywords: parametrical learning, creativeness of movements, learning under varying conditions, learning under standard conditions, pedagogical experiment.

Gauta 2006 m. rugsejjo $12 \mathrm{~d}$

Received on September 12, 2006

Priimta 2006 m. gruodžio $6 \mathrm{~d}$.

Accepted on December 6, 2006
Rima Bakienè

Lietuvos kūno kultūros akademija

(Lithuanian Academy of Physical Education)

Sporto g. 6, LT-44221 Kaunas

Lietuva (Lithuania)

Tel +370 37302653

E-mail r.bakiene@1kka.lt 